\title{
Chemical Composition, Antioxidant, Antimicrobial and Cytotoxic/Cytoprotective Activity of Non-Polar Extracts of Grape (Vitis labrusca cv. Bordeaux) and Blackberry (Rubus fruticosus) Seeds
}

Tufy Kabbas Junior ${ }^{1}$, Cristiane de Moura ${ }^{1}$, Mariana Araújo Vieira do Carmo ${ }^{2}$, Luciana Azevedo ${ }^{2}$, Luis Antônio Esmerino ${ }^{3}$, Rosangela Capuano Tardivo ${ }^{4}$, Petri Kilpeläinen ${ }^{5}$ and Daniel Granato ${ }^{6, *(D)}$

1 Graduate Program in Chemistry, State University of Ponta Grossa (UEPG), Av. Carlos Cavalcanti, 4748, Ponta Grossa 84030-900, Parana, Brazil; tufy_kj@hotmail.com (T.K.J.); tiane.moura@hotmail.com (C.d.M.)

2 Graduate Program in Biosciences Applied to Health, Federal University of Alfenas (UNIFAL), R. Nabor Toledo Lopes, 598-Parque das Nações, Alfenas 37130-000, Minas Gerais, Brazil; marianavieira06@hotmail.com (M.A.V.d.C.); lucianaazevedo2010@gmail.com (L.A.)

3 Department of Clinical Analysis, State University of Ponta Grossa, Av. Carlos Cavalcanti, 4748, Ponta Grossa 84030-900, Brazil; esmerino@uepg.br

check for updates

Citation: Junior, T.K.; de Moura, C.; do Carmo, M.A.V.; Azevedo, L.; Esmerino, L.A.; Tardivo, R.C.; Kilpeläinen, P.; Granato, D. Chemical Composition, Antioxidant, Antimicrobial and Cytotoxic/ Cytoprotective Activity of Non-Polar Extracts of Grape (Vitis labrusca cv. Bordeaux) and Blackberry (Rubus fruticosus) Seeds. Molecules 2021, 26, 4057. https://doi.org/10.3390/ molecules26134057

Academic Editors: José Pinela, Lillian Barros and Maria Ines Dias

Received: 1 June 2021

Accepted: 29 June 2021

Published: 2 July 2021

Publisher's Note: MDPI stays neutral with regard to jurisdictional claims in published maps and institutional affiliations.

Copyright: (c) 2021 by the authors. Licensee MDPI, Basel, Switzerland. This article is an open access article distributed under the terms and conditions of the Creative Commons Attribution (CC BY) license (https:// creativecommons.org/licenses/by/ $4.0 /)$.
4 Department of Biology, State University of Ponta Grossa, Av. Carlos Cavalcanti, 4748, Ponta Grossa 84030-900, Brazil; rc.tardivo@uol.com.br

5 Production Systems \& Biorefinery \& Bioproducts, Natural Resource Institute, Finland (Luke), Tietotie 2, FI-02150 Espoo, Finland; petri.kilpelainen@luke.fi

6 Department of Biological Sciences, Faculty of Science and Engineering, University of Limerick, V94 T9PX Limerick, Ireland

* Correspondence: daniel.granato@ul.ie

\begin{abstract}
The aim of this study was to compare the influence of the extraction method, chemical composition, antimicrobial effects, antioxidant activity, and cytotoxicity on human cells of the nonpolar extracts of grape (Vitis labrusca) and blackberry (Rubus fruticosus) seeds. The Soxhlet (Sox), Bligh-Dyer (BD), and ultrasound (US) methods were used for extractions. For blackberry nonpolar seed extract, extraction via the BD method showed the highest mean values of total phenolic content (TPC), expressed in milligrams of gallic acid equivalent per $100 \mathrm{~mL}$ of non-polar seed extracts (102.37 mg GAE/100 mL), and higher antioxidant activity in relation to the 2,2-diphenyl1-picrylhydrazyl (DPPH) radical, expressed in milligrams of gallic acid equivalent per $100 \mathrm{~mL}$ of non-polar seed extracts $(11.50 \mathrm{mg}$ AAE/100 mL), if compared with the Sox and US extractions. Similar results were obtained for the non-polar grape seed extracts, where BD extraction obtained the highest values for TPC (28.61 mg GAE/100 mL) and DPPH (35.36 mg AAE/100 mL). The type of extraction method had an impact on the composition of fatty acids. Only the non-polar blackberry and grape seed extracts obtained via the Sox method showed some in vitro inhibitory effect against Escherichia coli (IAL 2064) and Staphylococcus aureus (ATCC 13565). Regardless of the extraction method used, the non-polar blackberry and grape seed extracts did not decrease the cell viability $\left(\mathrm{IC}_{50}>1000 \mu \mathrm{g} / \mathrm{mL}\right.$ ) of cancer and normal cell lines, thus indicating the relative safety of the extracts. All the seed extracts decreased the generation of reactive oxygen species in the cell lines. Blackberry and grape seed lipid fractions can be utilized as antioxidants, and the extraction methods used cause significant changes in relation to their bioactivity and chemical composition.
\end{abstract}

Keywords: cell models; antioxidants; fruit seeds; fatty acids; in vitro bioactivity

\section{Introduction}

Due to their technological versatility, vegetable oils are used in the food, pharmaceutical, cosmetic, agronomic, sanitary, and fuel industries. Such oils can be extracted from flowers, leaves, branches, trunks, fruits, bark, seeds, and roots. The extraction of vegetable 
oils represents an important economic activity both in Brazil and worldwide, the most representative being oils extracted from soybeans (Glycine max L. Merrill), palm (Elaeis guineensis Jacq.), rice (Oryza sativa L.), cotton (Gossypium hirsutum), and sunflower seeds (Helianthus annuus) [1]. Species such as andiroba (Carapa guianensis), buriti (Mauritia flexuosa), copaiba (Copaifera sp.), pequi (Caryocar brasiliense Camb.), golden linseed (Linum usitatissimum), avocado (Persea americana cv. Butter), pomegranate (Punica granatum), and grapes (Vitis labrusca cv. Bordeaux) are also used in the production of oils in Brazil, however, these are less expressive, that is, on a smaller scale [2].

Vegetable oils are increasingly used because they present a complex mixture of compounds [3]. For example, some classes of compounds, such as fatty acids, phenolic compounds, carotenoids, tocopherols, and phytosterols, are present in vegetable oils and are responsible for antioxidant properties and beneficial health effects $[2,4,5]$. Triacylglycerols are formed from the combination of a glycerol molecule with three fatty acids, together with diacylglycerols, free fatty acids, and phospholipids they are the major components of edible vegetable oils (95-98\%) [6]. In addition, some vegetables oils are sources of essential fatty acids such as oleic, linoleic, and linolenic acid (olive, grape, canola, sunflower, corn, soy, etc.). This chemical composition can be influenced by factors such as harvest period, climatic conditions, region of cultivation, and extraction method, all of which can affect the functional properties of oils [7].

Studies have shown that the consumption of phenolic compounds is strongly related to the reduction of the risk of cancer, inflammatory disorders and cardiovascular diseases [8]. Santos et al. [9] studied the methanol/water $(90 / 10 v / v)$ extract of grape seed oil (Vitis labrusca cv. Bordeaux) obtained by cold pressing. They demonstrated antioxidant activity against the 2,2-diphenyl-1-picrylhydrazyl (DPPH) radical and 2,2'azino-bis (3-ethylbenzothiazoline-6-sulfonic acid) (ABTS). Deolindo et al. [10] showed that hydroethanolic extracts from grape seeds (Vitis labrusca cv. Bordeaux) have chemical antioxidant activity based on the DPPH assay, as well as the in vitro potential to inhibit the activity of the angiotensin I-converting enzyme (ACE-I). Harbeoui et al. [11] confirmed the anti-inflammatory capacity of the ethanol/water extract $(80 / 20, v / v)$ of Vitis vinifera grape seeds using RAW 264.7 cells. These authors also suggested that the different mechanisms involved in anti-inflammatory activity could be due to the synergism between various phenolic compounds as well as the specific structural elements of flavonoids (dominant fraction). Studies of the ethanol/acidic water extract ( $\mathrm{pH}$ 3.2) 7:3 $v / v$ from cold-pressed fresh grape seed oils, performed by Cecchi et al. [12], demonstrated in vitro inhibitory activity against PTP-1B (protein-tyrosine phosphatase 1B enzyme), an enzyme that is overexpressed in type 2 diabetes, with maximum inhibition values (98\%) for Vitis vinifera $\mathrm{cv}$. Sauvignon Blanc and minimum inhibition values (40\%) for Vitis vinifera cv. Cabernet Sauvignon. These authors suggested that inhibitory activity was exerted by the phenolic fraction isolated from these oils, and that further studies were required to confirm the action of grape seed oils and help to understand the mechanism behind this activity.

Micić et al. [13] analyzed the hexane extract from blackberry and raspberry seeds; they identified essential fatty acids (oleic, linoleic, and linolenic acids) as the major compounds. Blackberry is a fruit of interest because of its high content of anthocyanins and ellagitannins (ETs) in the pulp, as well as other phenolic compounds that contribute to its high antioxidant capacity. Blackberry pulp has previously shown protective activity against oxidative stress agents, endotoxicity, age-related neurodegenerative diseases, obesity, cancer, diabetes, and cardiovascular diseases [14-16].

In order to contribute to the existing knowledge about the relationship between chemical composition and biological activities of extracts obtained from agroindustry tailings, this study aimed to examine the effect of the extraction method (Soxhlet, BlighDyer, and ultrasound) on the antioxidant, antimicrobial, and cytotoxic properties on normal and cancerous cells, as well as the chemical composition of non-polar grape seed extracts (Vitis labrusca) and blackberry (Rubus fruticosus). 


\section{Results and Discussion}

\subsection{Total Phenolic Content and Antioxidant Activity}

The data regarding TPC, antioxidant activity, and yield (\%) are shown in Table 1. The yield obtained from the extractions were as follows: Sox (31.9 and 20.7\%); BD (20.0 and $13.3 \%$ ); and US (12.6 and $7.7 \%$ ) for grape and blackberry seeds, respectively, in each technique used. For the non-polar extracts of blackberry seeds, extraction via BD showed the highest mean values for TPC (102.37 mg GAE/100 mL) and antioxidant activity in relation to DPPH (11.50 mg AAE/100 mL). Regarding the total reducing capacity (TRC), expressed in milligrams of quercetin equivalent $(\mathrm{QE})$ per $100 \mathrm{~mL}$ of non-polar seed extracts, of the blackberry seed extracts, the extraction using BD (46.42 mg QE/100 mL) also showed the highest mean values $(p<0.05)$ compared to the other extractions (not detected). For the ability to chelate $\mathrm{Fe}^{2+}$, expressed in milligrams of ethylenediamine tetraacetic acid equivalent (EDTAE) per $100 \mathrm{~mL}$ of non-polar seed extracts, the highest mean values were found using extraction via Sox and US, (261.12 mg EDTAE/100 mL) and (77.57 mg ED$\mathrm{TAE} / 100 \mathrm{~mL}$ ) respectively, for blackberry extract. For the grape extract, the BD extraction showed the highest TPC (28.61 mg GAE/100 mL) and DPPH (35.36 mg AAE/100 mL). The values showed herein are lower than those found by Deolindo et al. [10], studying a Bordeaux grape seed extract obtained with ethanol/water (TPC $=3,886 \pm 124 \mathrm{mg}$ $\mathrm{GAE} / 100 \mathrm{~g}$, DPPH $=12,872 \pm 64 \mathrm{mg} \mathrm{AAE} / 100 \mathrm{~g}$ ). The ability to chelate $\mathrm{Fe}^{2+}$ (grape extract) showed higher values with Sox extraction $(155.01 \mathrm{mg}$ EDTAE/100 mL) and US (74.70 mg EDTAE/100 mL), differing only in relation to TRC activity, which presented the greatest activity with extraction via US.

Table 1. Total phenolic content and antioxidant activity of non-polar blackberry and grape seed extracts.

\begin{tabular}{|c|c|c|c|c|}
\hline & \multicolumn{3}{|c|}{ Non-Polar Blackberry Seed Extracts } & \multirow[b]{2}{*}{$p$-Value } \\
\hline & Sox & BD & US & \\
\hline TPC (mg GAE/100 mL) & $7.37 \pm 0.25$ & $102.37 \pm 4.38$ & $7.31 \pm 0.30$ & $<0.001$ \\
\hline DPPH (mg AAE/100 mL) & $6.91 \pm 0.10$ & $11.50 \pm 0.44$ & $2.07 \pm 0.13$ & $<0.001$ \\
\hline TRC (mg QE/100 mL) & ND & $46.42 \pm 1.64$ & ND & $<0.001$ \\
\hline $\begin{array}{l}\mathrm{Fe}^{2+} \text { chelating ability } \\
(\mathrm{mg} \text { EDTAE } / 100 \mathrm{~mL})\end{array}$ & $261.12 \pm 12.13$ & $17.12 \pm 0.43$ & $77.57 \pm 0.12$ & $<0.001$ \\
\hline \multirow[t]{3}{*}{ Yield (\%) } & 20.7 & 13.3 & 7.7 & \\
\hline & \multicolumn{3}{|c|}{ Non-Polar GrapeSeed Extracts } & \\
\hline & Sox & BD & US & $p$-Value \\
\hline TPC (mg GAE/100 mL) & $7.21 \pm 0.18$ & $28.61 \pm 0.50$ & $7.01 \pm 0.29$ & $<0.001$ \\
\hline DPPH (mg AAE/100 mL) & $6.18 \pm 0.39$ & $35.36 \pm 0.99$ & $3.95 \pm 0.20$ & $<0.001$ \\
\hline TRC (mg QE/100 mL) & ND & $19.36 \pm 0.34$ & $125.89 \pm 1.60$ & $<0.001$ \\
\hline $\begin{array}{l}\mathrm{Fe}^{2+} \text { chelating ability } \\
(\mathrm{mg} \text { EDTAE } / 100 \mathrm{~mL})\end{array}$ & $155.01 \pm 1.20$ & $18.62 \pm 0.13$ & $74.70 \pm 0.60$ & $<0.001$ \\
\hline Yield (\%) & 31.9 & 20.0 & 12.6 & \\
\hline
\end{tabular}

Note: Sox = Soxhlet, BD = Bligh-Dyer, US = ultrasound, GAE = gallic acid equivalent, AAE = ascorbic acid equivalent, $\mathrm{QE}=$ quercetin equivalent, $\mathrm{EDTAE}=$ ethylenediamine tetraacetic acid equivalent, $\mathrm{ND}=$ not detected, $\mathrm{TPC}=$ total phenolic content, $\mathrm{TRC}=$ total reducing capacity.

\subsection{Composition of Fatty Acids and Phytosterols}

The individual fatty acid and phytosterols contents of blackberry and grape non-polar seed extracts is shown in Table 2. There were significant differences $(p<0.05)$ between the three extraction methods: except for palmitic acid $(p=0.8746)$, linolenic acid $(p=0.7702)$, linoleic acid $(p=0.7155)$, oleic acid $(p=0.2824)$, stearic acid $(p=0.0605)$, and arachidic acid $(p=0.0524)$ for the blackberry non-polar seed extracts and linoleic ethyl ester $(p=0.0872)$ and monopalmitin $(p=0.1725)$ for the grape non-polar seed extracts. Blackberry extracted 
with US had the highest levels $(p<0.001)$ of $\beta$-sitosterol, $\beta$-amyrenol, and methylene cycloartenol, whereas for grape non-polar seed extracts the highest contents were arachidic acid, 9-octadecanoic acid, campesterol, stigmasterol, and $\beta$-sitosterol.

Table 2. Individual fatty acid compounds and phytosterols of blackberry and grape seed extracts.

\begin{tabular}{|c|c|c|c|c|}
\hline & \multicolumn{4}{|c|}{ Non-Polar Blackberry Seed Extracts (mg/mL of Extract) } \\
\hline & Sox & BD & US & $p$-Value \\
\hline Palmitic acid (16:0) & $1.00 \pm 0.27$ & $1.05 \pm 0.14$ & $0.98 \pm 0.05$ & 0.8746 \\
\hline Linolenic acid (18:3) & $0.11 \pm 0.02$ & $0.12 \pm 0.03$ & $0.12 \pm 0.01$ & 0.7702 \\
\hline Linoleic acid (18:2) & $6.88 \pm 2.34$ & $7.89 \pm 0.98$ & $7.69 \pm 0.87$ & 0.7155 \\
\hline Oleic acid (18:1) & $4.38 \pm 1.69$ & $6.42 \pm 1.68$ & $5.31 \pm 0.57$ & 0.2824 \\
\hline Stearic acid (18:0) & $0.44 \pm 0.05$ & $0.61 \pm 0.22$ & $0.29 \pm 0.02$ & 0.0605 \\
\hline Arachidic acid (20:0) & $0.25 \pm 0.13$ & $0.45 \pm 0.06$ & $0.42 \pm 0.01$ & 0.0524 \\
\hline Monopalmitin & $0.23 \pm 0.05^{\mathrm{a}}$ & $0.24 \pm 0.03^{\mathrm{a}}$ & $0.13 \pm 0.01^{b}$ & $0.0086^{*}$ \\
\hline Monostearin & $0.21 \pm 0.06^{\mathrm{ab}}$ & $0.26 \pm 0.01^{\mathrm{a}}$ & $0.15 \pm 0.01^{\mathrm{b}}$ & $0.0255^{*}$ \\
\hline Campesterol & $0.19 \pm 0.01^{b}$ & $0.21 \pm 0.00^{\mathrm{a}}$ & $0.21 \pm 0.01^{\mathrm{a}}$ & 0.0370 \\
\hline Stigmasterol & $0.27 \pm 0.01^{\mathrm{c}}$ & $0.36 \pm 0.02^{\mathrm{a}}$ & $0.32 \pm 0.02^{b}$ & 0.0012 \\
\hline$\beta$-sitosterol & $3.11 \pm 0.05^{b}$ & $3.55 \pm 0.06^{\mathrm{a}}$ & $3.62 \pm 0.05^{\mathrm{a}}$ & $<0.0001$ \\
\hline$\beta$-Amyrenol & $0.21 \pm 0.01^{b}$ & $0.22 \pm 0.01^{\mathrm{b}}$ & $0.26 \pm 0.01^{\mathrm{a}}$ & 0.0006 \\
\hline \multirow[t]{3}{*}{ Methylene cycloartenol } & $0.45 \pm 0.02^{b}$ & $0.42 \pm 0.02^{\mathrm{c}}$ & $0.57 \pm 0.01^{\mathrm{a}}$ & $<0.0001$ \\
\hline & \multicolumn{4}{|c|}{ Non-Polar Grape Seed Extracts (mg/mL of Extract) } \\
\hline & Sox & BD & US & $p$-Value \\
\hline Palmitic acid (16:0) & $1.47 \pm 0.16^{b}$ & $1.80 \pm 0.06^{\mathrm{a}}$ & $1.75 \pm 0.09^{\mathrm{a}}$ & 0.0212 \\
\hline Linolenic acid (18:3) & $0.38 \pm 0.04$ & $0.33 \pm 0.01$ & $0.38 \pm 0.02$ & 0.0872 \\
\hline Linoleic acid (18:2) & $5.17 \pm 1.20^{b}$ & $7.05 \pm 0.244^{a b}$ & $8.19 \pm 1.14^{\mathrm{a}}$ & 0.0233 \\
\hline Oleic acid (18:1) & $3.53 \pm 0.62^{b}$ & $4.71 \pm 0.30^{a b}$ & $5.43 \pm 1.00^{\mathrm{a}}$ & 0.0414 \\
\hline Stearic acid (18:0) & $0.38 \pm 0.04^{\mathrm{c}}$ & $0.66 \pm 0.02^{\mathrm{a}}$ & $0.51 \pm 0.08^{b}$ & 0.0023 \\
\hline Arachidic acid (20:0) & $0.24 \pm 0.02^{a}$ & $0.16 \pm 0.01^{\mathrm{b}}$ & $0.16 \pm 0.02^{b}$ & 0.0009 \\
\hline Monopalmitin & $0.09 \pm 0.02$ & $0.12 \pm 0.01$ & $0.10 \pm 0.01$ & 0.1725 \\
\hline Monostearin & $0.03 \pm 0.01^{\mathrm{a}}$ & $0.05 \pm 0.00^{\mathrm{a}}$ & $0.03 \pm 0.01^{\mathrm{a}}$ & 0.0024 \\
\hline Campesterol & $0.25 \pm 0.01^{b}$ & $0.28 \pm 0.02^{b}$ & $0.58 \pm 0.09^{a}$ & 0.0004 \\
\hline Stigmasterol & $0.24 \pm 0.01^{b}$ & $0.29 \pm 0.01^{\mathrm{a}}$ & $0.22 \pm 0.01^{b}$ & 0.0002 \\
\hline$\beta$-Sitosterol & $1.3 \pm 0.02^{b}$ & $1.56 \pm 0.01^{\mathrm{a}}$ & $1.22 \pm 0.03^{c}$ & $<0.0001$ \\
\hline
\end{tabular}

The proportion of linoleic acid (18:2) $42-52 \%$ in grape seed extract fatty acids was lower than those reported in the literature for grape (Vitis sp.) seed oil: 63-75\% [17] and $66-75 \%$ [18]. The oleic acid (18:1) proportion was 29-37\%, palmitic acid (16:0) $10-14 \%$, stearic acid (C18:0) 3-5\%, linolenic acid 2-4\% (C18:3), and arachidic acid $1-3 \%$ of fatty acids in extracts.

Fatty acid proportions of blackcurrant extracts were $44-53 \%$ linoleic acid (18:2), 31-42\% oleic acid (18:1), 6-9\% palmitic acid (16:0), 2-5\% stearic acid, 1\% linolenic acid (18:3), and $1-3 \%$ arachidic acid (20:0). Proportions of linoleic acid are lower and oleic acid higher than in the literature [13], where values were $66 \%$ and $13 \%$. Extractions were done with hexane with a different extraction set-up and at a lower extraction temperature $\left(4^{\circ} \mathrm{C}\right)$ than this study, which could explain the differences in proportions of fatty acids in extracts. 


\subsection{Antimicrobial Activity}

Antimicrobial activity was tested against Escherichia coli (IAL 2064) and Staphylococcus aureus (ATCC 13565). The results showed that only the non-polar blackberry and grape seed extracts obtained via Sox presented some inhibitory effect. The blackberry extract inhibition values in relation to E. coli (IAL 2064) were $99.4 \%, 62.5 \%, 33.8 \%$, and $33.4 \%$ for concentrations of 33.3, 1.67, 0.83, and $0.42 \mu \mathrm{g} / \mathrm{L}$, respectively. For S. aureus (ATCC 13565), the inhibition values of the blackberry extract were $90.7 \%$, and $33.3 \%$ for concentrations of 33.3 and $1.67 \mu \mathrm{g} / \mathrm{L}$, respectively. Studies of the antimicrobial capacity of non-polar blackberry seed extracts are not reported in the literature. Weli et al. [19] studied the antibacterial activity of blackberry leaf extracts (methanol, hexane, chloroform, ethyl acetate, and hydro-alcoholic) and concluded that they are effective against several Grampositive and Gram-negative micro-organisms.

The non-polar grape seed extract obtained via Sox showed inhibition against $E$. coli (IAL 2064) at concentrations of 33.3, 1.67, and $0.83 \mu \mathrm{g} / \mathrm{L}$ with values of $92.7 \%, 49.9 \%$, and $34.4 \%$ inhibition and against S. aureus (ATCC 13565) with values of $85.1 \%$ and $36.6 \%$ inhibition at concentrations of 33.3 and $1.67 \mu \mathrm{g} / \mathrm{L}$, respectively.

A study conducted by Duran et al. [20] demonstrated the antimicrobial effect of grape seeds by using chitosan-coated extracts to prolong the lifespan of fresh strawberries. The antimicrobial activity of grape pomace was described by Leal et al. [21], and the authors concluded that grape stems demonstrated antimicrobial activity, with high efficiency against Gram-positive bacteria, especially S. aureus and E. faecalis.

\subsection{Determination of Cellular Toxicity of the Non-Polar Seed Extracts and Measurement of ROS (Reactive Oxygen Species)}

A range of non-polar seed extract concentrations (from 100 to $1000 \mu \mathrm{g} / \mathrm{mL}$ ) was used to assess the cell viability in A549, Caco-2, HepG2 and IMR90 cell lines. Both blackberry and grape non-polar seed extracts, independent of extraction method, did not decrease the cell viability $\left(\mathrm{IC}_{50}>1000 \mu \mathrm{g} / \mathrm{mL}\right.$ ) for cancer and normal cell lines (Figure 1). Conversely, Montserrat-de la Paz et al. [22] exhibited that the isolated $\beta$-sitosterol, one of the main fatty acids present in the blackberry and grape non-polar seed extracts (from 1.22 to $3.66 \mathrm{mg} / \mathrm{g})$, reduced the cell viability $\left(\mathrm{IC}_{50}=79.0 \mu \mathrm{M}\right)$ in HT-29 cancer cells. Taking this into account, it is important to consider that there are differences between working with individual compounds ( $\beta$-sitosterol) and whole natural matrices (i.e., non-polar seed extracts). Thus, the final biological potential is not always the sum of each one of the individual compounds present in the non-polar seed extracts, as different interactions may occur in biological media [23].

Regarding the intracellular antioxidant capacity (Figure 2), the US and Sox blackberry and grape non-polar seed extracts obtained via US were not able to induce ROS generation in all cell lines. When $\mathrm{H}_{2} \mathrm{O}_{2}$ was added, the non-polar seed extracts decreased the intracellular ROS levels and, in some cases, the ROS generation was similar to that of the negative control group. In contrast, grape non-polar seed extracts obtained via Sox promoted pro-oxidant behavior by inducing ROS production in both cancer and normal cells. This finding may be associated with the antioxidant activity measured using chemical methods, especially the TRC assay. Interestingly, the TRC levels were not detected for both blackberry and grape extracts obtained via Sox. In contrast, grape and blackberry non-polar seed extracts obtained using the BD method exhibited high antioxidant capacity by decreasing the ROS rate by up to $32 \%$ or maintaining their levels similar to the control. Similarly, Atolani et al. [24] showed that Citrus sinensis non-polar seed extracts also reduced the ROS rate by $50 \%$ when compared with the negative control (no addition of the oxidant agent). Additionally, Kouka et al. [25] pointed out that the phenolic fraction of olive oil did not affect the ROS levels in C2C12 and HeLLa cell lines, apart from HepG2, where ROS decreased significantly. Thus, in the present study, the intracellular antioxidant potential of grape and blackberry seed extracts obtained via BD extraction was increased for IMR90, A549, HepG2, and Caco-2 cells. This result is in agreement with the higher 
DPPH scavenging activity $(11.50 \pm 0.44$ and $35.3 \pm 0.99 \mathrm{mg}$ AAE $/ 100 \mathrm{~mL}$ for blackberry and grape seed extracts, respectively) and TPC content (102.37 \pm 4.38 and $28.61 \pm 0.5 \mathrm{mg}$ $\mathrm{GAE} / 100 \mathrm{~mL}$ for blackberry and grape seed extracts, respectively) displayed herein for the BD method.
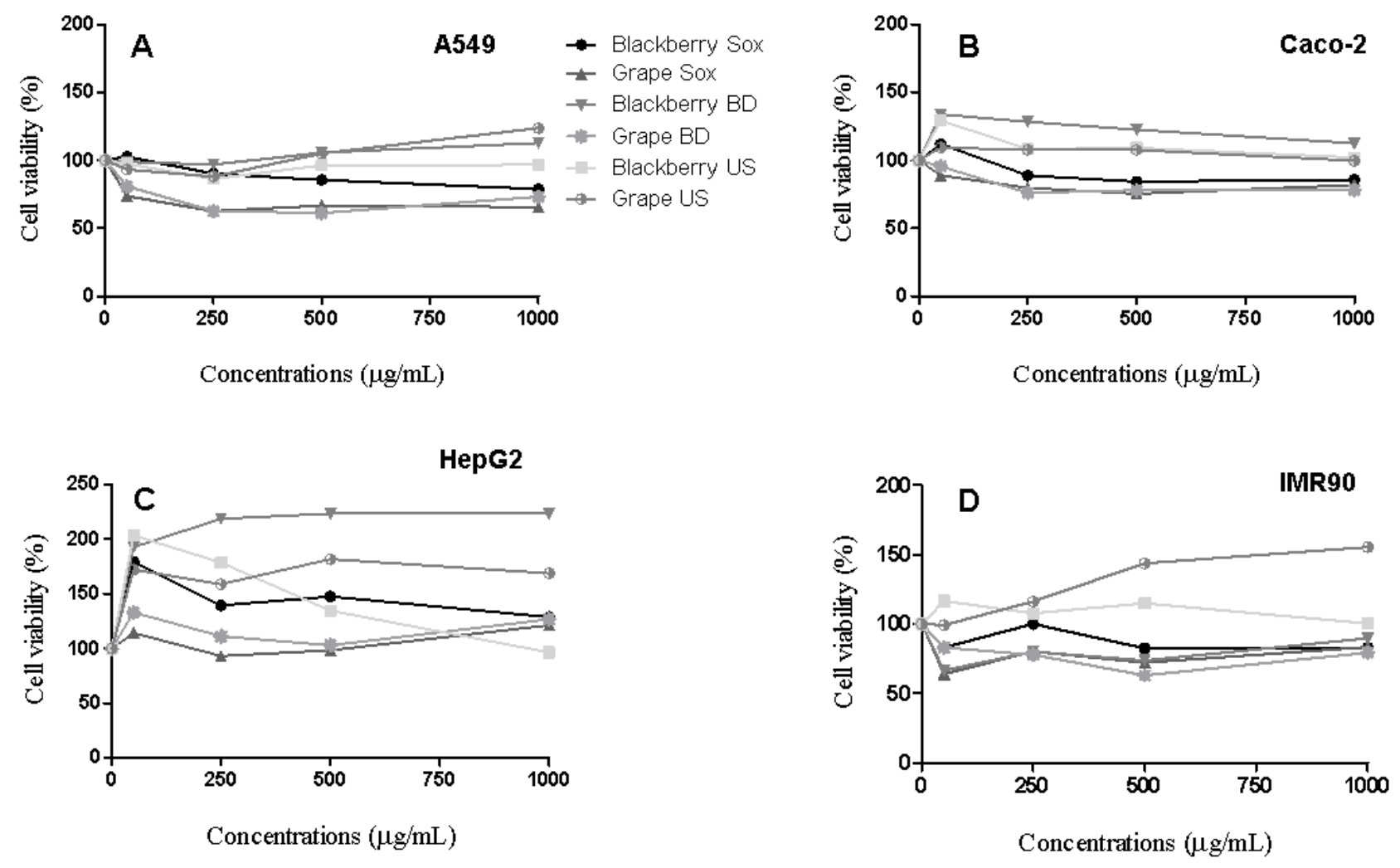

Figure 1. Representative cell viability of A549 (A) Caco-2 (B), HepG2 (C), and IMR90 (D) cells after 48 h exposure to non-polar blackberry and grape seed extracts.

BLACKBERRY SOX

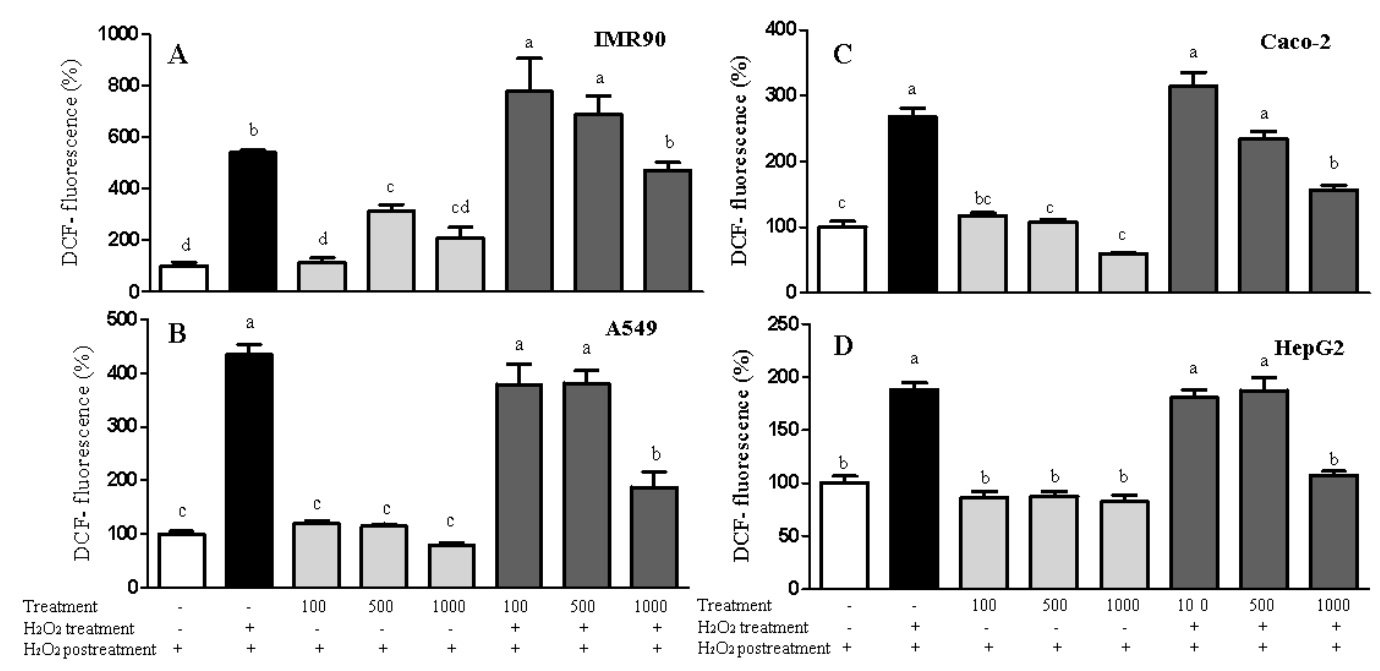

Figure 2. Cont. 
GRAPE SOX
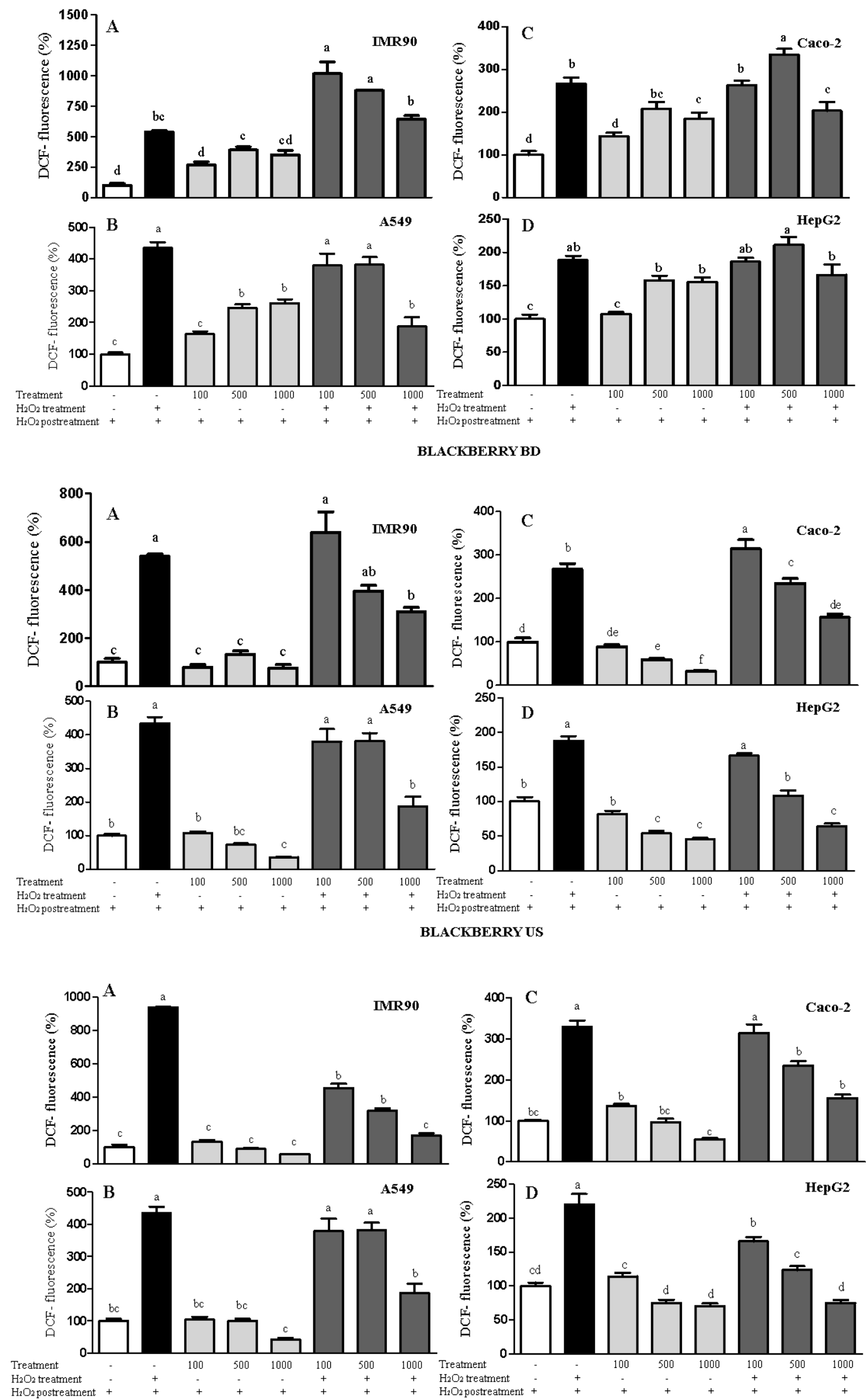

Figure 2. Cont. 
BLACKBERRY US
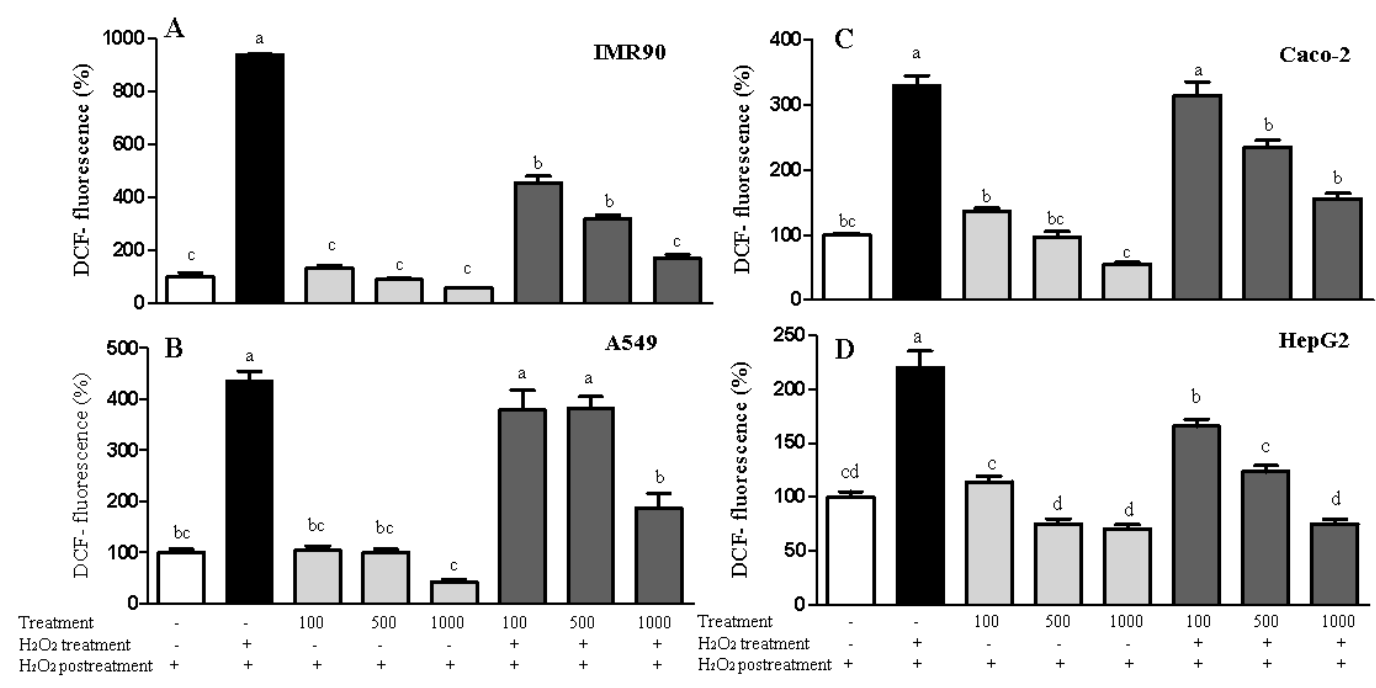

GRAPE US

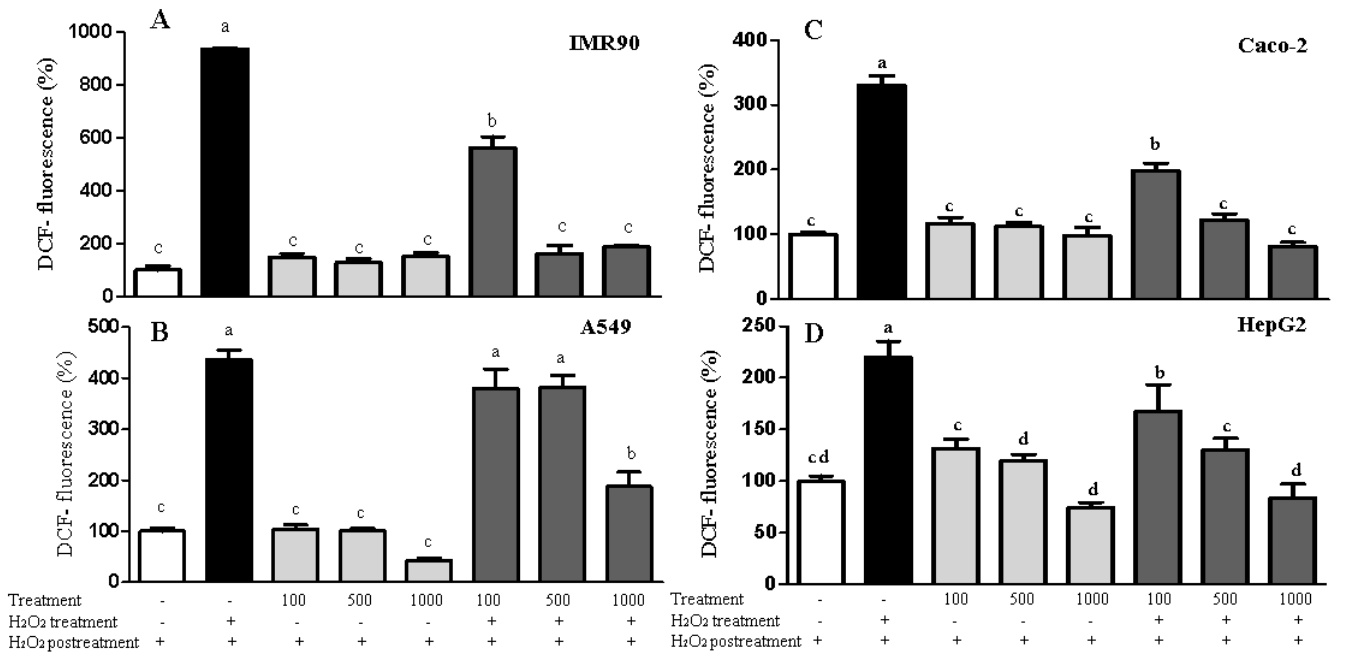

Figure 2. Results of the measurement of intracellular ROS in IMR90 (A), A549 (B), Caco-2 (C), and HepG2 (D) cells via spectrofluorimetry. Treatment $=$ non-polar blackberry and grape seed extracts at 100-1000 $\mu \mathrm{g} / \mathrm{mL}$. Different letters comparing the treatments represent statistically different results at $p<0.05$.

\section{Materials and Methods}

\subsection{Reagents}

Folin-Ciocalteu reagent, isobutanol, quercetin (95\% purity), sodium hydroxide $(\mathrm{NaOH})$, 2,2-diphenyl-1-picryl-hydrazyl radical (DPPH), pyrocatechol violet (3,3',4-trihydroxyfuchsone-2'-sulfonic acid), 2,4,6-tris (2-pyridyl)-S-triazine (TPTZ), hydrogen peroxide, hyeneicosanoic acid (C:21), cholesterol, dimethyl sulfoxide (DMSO), 2', $7^{\prime}$-dichlorofluorescin diacetate (DCFH-DA), ferric chloride hexahydrate, ascorbic acid, and ferrozine 3-(2-Pyridyl)5,6-di (2-furyl)-1,2,4-triazine-5', $5^{\prime \prime}$-disulfonic acid disodium salt) were obtained from SigmaAldrich (São Paulo, Brazil). Anhydrous sodium sulfate, n-hexane, chloroform, and methanol were obtained from Anhydrol (São Paulo, Brazil). Ethanol was purchased from Neon (São Paulo, Brazil). The A549, IMR90, HepG2 and Caco-2 cells were obtained from the Cell Bank of Rio de Janeiro, Brazil. 


\subsection{Plant Materials}

Blackberry (Rubus fruticosus) and purple grape (Vitis labrusca cv. Bordeaux) were grown in Vacaria, Rio Grande do Sul $\left(29^{\circ} 32^{\prime} 30^{\prime \prime} \mathrm{S}\right.$ and $\left.50^{\circ} 54^{\prime} 51^{\prime \prime} \mathrm{W}\right)$ and Garibaldi, Rio Grande do Sul $\left(29^{\circ} 15^{\prime} 22^{\prime \prime} \mathrm{S}\right.$ and $\left.51^{\circ} 32^{\prime} 01^{\prime \prime} \mathrm{W}\right)$, Brazil. The fruits (blackberry and grape), together with the leaves and flowers, were identified morphologically and exsiccates of plant material were deposited in the Herbarium of the State University of Ponta Grossa, Paraná, Brazil, under numbers 22,494 and 22,495, respectively. The grape seeds were obtained directly from a grape juice producer and the material was dried $\left(35^{\circ} \mathrm{C} / 48 \mathrm{~h}\right)$ and ground (Tyler 60 mesh sieve). The blackberry seeds were obtained manually and went through the processes of sanitizing using $\mathrm{NaOCl}$ at $100 \mathrm{mg} / \mathrm{L}$ for $15 \mathrm{~min}$, washing (running water), drying (greenhouse with air circulation (Tecnical, Model TE-393/1, São Paulo, Brazil) at $35{ }^{\circ} \mathrm{C}$ for $48 \mathrm{~h}$, grinding (analytical mill (QUIMIS-6298A21), standardization (Tyler 60 mesh sieve), and storage under refrigeration.

\subsection{Extraction Procedure}

In order to compare the chemical composition and bioactivity of the extracts, three methodologies were tested to obtain the non-polar extracts: Soxhlet, Bligh-Dyer and ultrasound.

\subsubsection{Extraction with Hot Solvent (Soxhlet)}

Five grams of the ground sample were weighed and transferred to the extraction cartridge. The extractions were performed in periods of $4-5 \mathrm{~h}$ in a Soxhlet apparatus with $\mathrm{n}$-hexane as the extraction solvent. The temperature was kept constant in the extraction apparatus within the boiling range of $\mathrm{n}$-hexane $\left(68-70^{\circ} \mathrm{C}\right)$. The extract was evaporated to remove the solvent through a vacuum evaporator $\left(35^{\circ} \mathrm{C}\right)$.

\subsubsection{Extraction Using the Bligh-Dyer Method}

For the extraction, approximately $5.0 \mathrm{~g}$ of each sample were weighed. In an Erlenmeyer flask, $20 \mathrm{~mL}$ of methanol, $10 \mathrm{~mL}$ of chloroform, and $8 \mathrm{~mL}$ of water (volume dependent on the moisture content of the sample) were added. After $30 \mathrm{~min}$ of stirring, an additional $10 \mathrm{~mL}$ of chloroform and $10 \mathrm{~mL}$ of $1.0 \% w / v$ sodium sulfate solution were added. The mixture was stirred again for $2 \mathrm{~min}$. The lower layer was removed and approximately $1.0 \mathrm{~g}$ of anhydrous sodium sulfate was added to remove traces of water, followed by filtration with qualitative filter paper. The solvent was removed using a vacuum evaporator.

\subsubsection{Ultrasound-Assisted Extraction}

Ultrasound equipment (Unique, model USC-1450A, Brazil), at $130 \mathrm{~W}$ and $20 \mathrm{kHz}$, was used for ultrasound-assisted extraction in pulse mode. A $5.0 \mathrm{~g}$ sample was weighed and mixed with $100 \mathrm{~mL}$ of hexane. During the extraction process the container was kept in a thermostat-controlled water bath $\left(25^{\circ} \mathrm{C}\right)$. In all the experiments, the extracts were collected after $40 \mathrm{~min}$. The resulting extracts were evaporated using a vacuum evaporator.

\subsection{Total Phenolic Content and Antioxidant Activity}

After obtaining the non-polar seed extracts, a liquid-liquid extraction was performed following the procedures described by de Santana et al. [26], with modifications. For $250 \mu \mathrm{L}$ of non-polar seed extracts, an aliquot of $500 \mu \mathrm{L}$ of methanol and water, in the proportion of $90 / 10 \mathrm{v} / \mathrm{v}$, was added to polystyrene microtubes, and the content was vortexed for $5 \mathrm{~min}$. The upper phase was collected and the non-polar seed extracts were extracted again. The extracts were kept at $-18{ }^{\circ} \mathrm{C}$.

The total phenolic content was evaluated using the Folin-Ciocalteu assay following the methodology described by Margraf et al. [27]. TPC was expressed in milligrams of gallic acid equivalent per $100 \mathrm{~mL}$ of non-polar seed extracts (mg GAE/100 mL). The capture of the DPPH radical was evaluated in a buffered system at $\mathrm{pH} 6$, using the experimental conditions described by Santos, Brizola and Granato [28]. The absorbance was at $525 \mathrm{~nm}$ 
and the data were expressed in milligrams of ascorbic acid equivalent per $100 \mathrm{~mL}$ of non-polar seed extracts (mg AAE/100 mL).

The determination of the TRC of the extracts was based on the Folin-Ciocalteu method modified by Berker et al. [29]. The absorbance was at $665 \mathrm{~nm}$, using a microplate reader (Biotek, model Epoch, Winooski, VT, USA). The analyses were performed in triplicate and the results were expressed in milligrams of quercetin equivalent per $100 \mathrm{~mL}$ of non-polar seed extracts (mg QE/100 mL).

The $\mathrm{Fe}^{2+}$ chelating ability of the extracts was evaluated using the colorimetric method proposed by Carter [30], adapted to the microplate reader [28]. The formation of the complex was calculated by Equation (1). The results were expressed in milligrams of ethylenediamine tetraacetic acid equivalent per $100 \mathrm{~mL}$ of non-polar seed extracts (mg EDTAE/100 mL).

$\mathrm{Fe}^{2+}$ chelating capacity $(\%)=(($ Abs sample - Abs blank $) /$ Abs control $) \times 100$

\subsection{Chemical Composition by Gas Chromatography-Mass Spectrometry (GC-MS)}

For the GC-MS analysis, each sample $(1 \mathrm{~mL})$ was silylated by adding $100 \mu \mathrm{L}$ pyridine, $100 \mu \mathrm{L}$ of N,O-Bis(trimethylsilyl)trifluoroacetamide (BSTFA), and $50 \mu \mathrm{L}$ of trimethylsilyl chloride (TMCS). The samples were analyzed using an HP 6890 GC system equipped with a 7683 automatic sampler, a 5973 selective mass detector, and a Zebron ZB SemiVolatiles capillary column $(30 \mathrm{~m} \times 0.25 \mathrm{~mm}$ id; $0.25 \mu \mathrm{m}$ film thickness). Helium was used as carrier gas at a flow rate of $1.5 \mathrm{~mL} / \mathrm{min}$. Heneicosanoic acid (C:21) and cholesterol were used as internal standards. The GC-MS used the following conditions: initial temperature of $150{ }^{\circ} \mathrm{C}$, temperature rate $7{ }^{\circ} \mathrm{C} / \mathrm{min}$ for temperature $230^{\circ} \mathrm{C}$ and $4{ }^{\circ} \mathrm{C} / \mathrm{min}$ for temperature $290{ }^{\circ} \mathrm{C}$, waiting time $15 \mathrm{~min}$, injector temperature $280^{\circ} \mathrm{C}$ and $1: 10$ ratio, MS interface temperature of $300^{\circ} \mathrm{C}$, ion source temperature of $230^{\circ} \mathrm{C}$, and quadrupole temperature of $150^{\circ} \mathrm{C}$. Results were calculated with the internal standard and were in the linear range of the MS detector. Repeatability of the method, expressed by the relative standard deviation between analyses, was below $5 \%$. The mass spectra were obtained via ionization energy by electronic impact (EI mode) $70 \mathrm{eV}$ between $\mathrm{m} / z 50$ to 800, following the method described by Väisänen et al. [31]. The fatty acids and phytosterols were identified by using the NIST14 and Wiley11 mass spectrometry libraries, as well as the laboratory's own library. The identification results were compared with the known retention times of the analytes and were expressed in milligrams per milliliter of the non-polar seed extract $(\mathrm{mg} / \mathrm{mL})$.

\subsection{Antimicrobial Activity}

\subsubsection{Minimum Inhibitory Concentration (MIC)}

The minimum inhibitory concentration (MIC) of the extracts was evaluated according to the microdilution plate technique, using 96-well microplates, adapted from the Clinical Laboratory Standards Institute (CLSI, 2014). The extracts were tested in concentrations of 3.33, 1.67, 0.83, and $0.42 \mu \mathrm{g} / \mathrm{L}$ against E. coli (IAL 2064) and S. aureus (ATCC 13565). The tests were standardized in sterile physiological solution equivalent to a $0.5 \mathrm{McF}$ arland standard. The negative controls were the culture medium, and the positive controls were the culture medium added to the tested microorganism. The plates were incubated at $35^{\circ} \mathrm{C}$ for $24 \mathrm{~h}$. The antimicrobial activity was calculated by the differences between the average of the optical density readings (OD) of the sample and its blank spaces (three readings were recorded after shaking at $620 \mathrm{~nm}$ ). Inhibition values were considered significant above 30\% and $p<0.05$.

\subsubsection{Cytotoxicity Analysis \\ Cell Viability}

The in vitro cell viability of grape and blackberry non-polar seed extracts was evaluated in relation to A549, IMR90, HepG2, and Caco-2 cell lines via the MTT assay [32]. Briefly, cells $\left(1 \times 10^{4}\right.$ cells/well $)$ were seeded into 96-well microplates and treated for $48 \mathrm{~h}$ with 50 , 
250, 500, and $1000 \mu \mathrm{g} / \mathrm{mL}$ of grape and blackberry non-polar seed extracts, which were diluted in DMSO and Tween 80 at final concentrations of $0.35 \%$ and $0.0009 \%$, respectively, for all wells. The optical density (OD) was measured at $570 \mathrm{~nm}$ and percent cell viability relative to the control was calculated using the following formula, $(\%)=\left(\mathrm{OD}_{\text {treatment }}-\right.$ $\left.\mathrm{OD}_{\text {blank }}\right) /\left(\mathrm{OD}_{\text {control }}-\mathrm{OD}_{\text {blank }}\right) \times 100$. The data were used to calculate $\mathrm{IC}_{50}$ values by non-linear regression.

\section{Cellular Antioxidant Activity}

The intracellular antioxidant potential of grape and blackberry nonpolar seed extracts was evaluated in A549, Caco-2, HepG2 $\left(6 \times 10^{4}\right.$ per well $)$ and IMR90 $\left(2 \times 10^{4}\right.$ per well $)$ cell lines. Cells were treated with 100, 500, and $1000 \mu \mathrm{g} / \mathrm{mL}$ of extracts diluted in a $25 \mathrm{mmol} / \mathrm{L}$ DCFH-DA $\left(2^{\prime}, 7^{\prime}\right.$-dichlorofluorescin diacetate) solution with and without $15 \mu \mathrm{mol} / \mathrm{L} \mathrm{H}_{2} \mathrm{O}_{2}$. Cells were then incubated at $37{ }^{\circ} \mathrm{C}$ for $1 \mathrm{~h}$ with the treatments and subsequently they were washed with PBS and an $\mathrm{H}_{2} \mathrm{O}_{2}$ solution $(15 \mu \mathrm{mol} / \mathrm{L})$ was added in the wells. The positive control was treated with $15 \mu \mathrm{mol} / \mathrm{L} \mathrm{H}_{2} \mathrm{O}_{2}$ and negative control only with culture medium. The fluorescence intensity was measured at an excitation wavelength of $485 \mathrm{~nm}$ and at an emission wavelength of $538 \mathrm{~nm}$. The data were expressed as percentage of fluorescence intensity [33].

\subsection{Statistical Analysis}

The experimental data were presented as rates \pm sample standard deviation. When appropriate, the comparison of rates between the groups was performed by a unifactorial analysis of variance (ANOVA), followed by a Fisher's multiple comparison test. For this, the homoscedasticity of the entire data set was formally verified using the Brown-Forsythe test using the TIBCO Statistica 13.3 (TIBCO Software Ltd., Palo Alto, CA, USA) software.

To correlate the bioactivity with the chemical composition of the non-polar seed extracts, the correlation coefficients were calculated. This analysis helps to understand which phenolic compound is responsible for the functional property in vitro [34].

\section{Conclusions}

The non-polar seed extracts obtained using the BD method showed the highest levels of total phenolic compounds and antioxidant activity for both blackberry and grape; however, only the extracts obtained via Sox showed an inhibitory effect against Escherichia coli (IAL 2064) and Staphylococcus aureus (ATCC 13565). As for cell viability, the non-polar extracts did not show cytotoxicity or antiproliferative effect in the different cell lines, which shows their relative toxicological safety. Considering the requirements of Agenda 2030 and the need for sustainable ways to produce food ingredients, we have concluded that grape and blackberry seeds can be used as sources of derived lipid antioxidants in different technological applications.

Author Contributions: Conceptualization, T.K.J.; Data curation, T.K.J.; Formal analysis, T.K.J., C.d.M., M.A.V.d.C., L.A., L.A.E., R.C.T. and P.K.; Investigation, T.K.J.; Methodology, D.G.; Project administration, T.K.J.; Resources, T.K.J.; Software, D.G.; Supervision, D.G.; Writing—original draft, T.K.J., C.d.M., M.A.V.d.C., L.A., L.A.E., R.C.T., P.K. and D.G. All authors have read and agreed to the published version of the manuscript.

Funding: This project was partially funded by Coordination for the Improvement of Higher Education Personnel, CAPES (PhD grants for TKJ and CdM). This research received no external funding.

Institutional Review Board Statement: Not applicable.

Informed Consent Statement: Not available.

Data Availability Statement: Not available.

Acknowledgments: The authors thank CAPES (Coordination for the Improvement of Higher Education Personnel) for the PhD scholarship (T. Kabbas Junior, Technical code 001). 
Conflicts of Interest: The authors declare no conflict of interest.

Sample Availability: Samples of the extracts are available from the authors.

\section{References}

1. Villela, A.A.; Jaccoud, D.B.; Rosa, L.P.; Freitas, M.V. Status and prospects of oil palm in the Brazilian Amazon. Biomass Bioenergy 2014, 67, 270-278. [CrossRef]

2. Santos, A.; Fernandes, C.; Lopes, L.; Sousa, A. Use of plant oils from the southwestern Amazon for the control of maize weevil. J. Stored Prod. Res. 2015, 63, 67-70. [CrossRef]

3. Nazzaro, F.; Fratianni, F.; De Martino, L.; Coppola, R.; De Feo, V. Effect of Essential Oils on Pathogenic Bacteria. Pharmaceuticals 2013, 6, 1451-1474. [CrossRef]

4. Fernandes, L.; Pereira, J.A.; Cortés, I.L.; Salazar, D.M.; Ramalhosa, E.; Casal, S. Fatty acid, vitamin E and sterols composition of seed oils from nine different pomegranate (Punica granatum L.) cultivars grown in Spain. J. Food Compos. Anal. 2015, 39, 13-22. [CrossRef]

5. Wang, H.; Wang, J.; Qiu, C.; Ye, Y.; Guo, X.; Chen, G.; Li, T.; Wang, Y.; Fu, X.; Liu, R.H. Comparison of phytochemical profiles and health benefits in fiber and oil flaxseeds (Linum usitatissimum L.). Food Chem. 2017, 214, 227-233. [CrossRef] [PubMed]

6. Indelicato, S.; Bongiorno, D.; Pitonzo, R.; Di Stefano, V.; Calabrese, V.; Indelicato, S.; Avellone, G. Triacylglycerols (TAGs) in edible oils: Determination, characterization, quantitation, chemometric approach and evaluation of adulterations. J. Cromatogr. A 2017, 1515, 1-16. [CrossRef]

7. Siddique, A.; Rahman, S.M.; Hossain, M.A. Chemical composition of essential oil by different extraction methods and fatty acid analysis of the leaves of Stevia Rebaudiana Bertoni. Arab. J. Chem. 2016, 9, S1185-S1189. [CrossRef]

8. Fernández-Ochoa, Álvaro; Borrás-Linares, I.; Pérez-Sánchez, A.; Barrajón-Catalán, E.; Gonzalez-Alvarez, I.; Arraez-Roman, D.; Micol, V.; Carretero, A.S. Phenolic compounds in rosemary as potential source of bioactive compounds against colorectal cancer: In situ absorption and metabolism study. J. Funct. Foods 2017, 33, 202-210. [CrossRef]

9. Santos, J.S.; Escher, G.B.; Pereira, J.M.D.S.; Marinho, M.T.; Prado-Silva, L.D.; Sant'Ana, A.S.; Dutra, L.; Barison, A.; Granato, D. 1H NMR combined with chemometrics tools for rapid characterization of edible oils and their biological properties. Ind. Crops Prod. 2018, 116, 191-200. [CrossRef]

10. Deolindo, C.T.P.; Monteiro, P.I.; Santos, J.S.; Cruz, A.G.; da Silva, M.C.; Granato, D. Phenolic-rich Petit Suisse cheese manufactured with organic Bordeaux grape juice, skin, and seed extract: Technological, sensory, and functional properties. LWT 2019, 115, 108493. [CrossRef]

11. Harbeoui, H.; Hichami, A.; Wannes, W.A.; Lemput, J.; Tounsi, M.S.; Khan, N.A. Anti-inflammatory effect of grape (Vitis vinifera L.) seed extract through the downregulation of NF-кB and MAPK pathways in LPS-induced RAW264.7 macrophages. S. Afr. J. Bot. 2019, 125, 1-8. [CrossRef]

12. Cecchi, L.; Innocenti, M.; Urciuoli, S.; Arlorio, M.; Paoli, P.; Mulinacci, N. In depth study of phenolic profile and PTP-1B inhibitory power of cold-pressed grape seed oils of different varieties. Food Chem. 2019, 271, 380-387. [CrossRef]

13. Micić, D.M.; Ostojic, S.; Simonovic, M.; Krstić, G.; Pezo, L.; Simonović, B.R. Kinetics of blackberry and raspberry seed oils oxidation by DSC. Thermochim. Acta 2015, 601,39-44. [CrossRef]

14. Kaume, L.; Howard, L.R.; Devareddy, L. The Blackberry Fruit: A Review on Its Composition and Chemistry, Metabolism and Bioavailability, and Health Benefits. J. Agric. Food Chem. 2011, 60, 5716-5727. [CrossRef]

15. Sautebin, L.; Rossi, A.; Serraino, I.; Dugo, P.; Di Paola, R.; Mondello, L.; Genovese, T.; Britti, D.; Peli, A.; Dugo, G.; et al. Effect of Anthocyanins Contained in a Blackberry Extract on the Circulatory Failure and Multiple Organ Dysfunction Caused by Endotoxin in the Rat. Planta Medica 2004, 70, 745-752. [CrossRef]

16. Serraino, I.; Dugo, L.; Dugo, P.; Mondello, L.; Mazzon, E.; Dugo, G.; Caputi, A.P.; Cuzzocrea, S. Protective effects of cyanidin-3-Oglucoside from blackberry extract against peroxynitrite-induced endothelial dysfunction and vascular failure. Life Sci. 2003, 73, 1097-1114. [CrossRef]

17. Crews, C.; Hough, P.; Godward, J.; Brereton, P.; Lees, M.; Guiet, S.; Winkelmann, W. Quantitation of the Main Constituents of Some Authentic Grape-Seed Oils of Different Origin. J. Agric. Food Chem. 2006, 54, 6261-6265. [CrossRef]

18. Lutterodt, H.; Slavin, M.; Whent, M.; Turner, E.; Yu, L. (Lucy) Fatty acid composition, oxidative stability, antioxidant and antiproliferative properties of selected cold-pressed grape seed oils and flours. Food Chem. 2011, 128, 391-399. [CrossRef]

19. Weli, A.M.; Al-Saadi, H.S.; Al-Fudhaili, R.S.; Hossain, A.; Putit, Z.B.; Jasim, M.K. Cytotoxic and antimicrobial potential of different leaves extracts of R. fruticosus used traditionally to treat diabetes. Toxicol. Rep. 2020, 7, 183-187. [CrossRef]

20. Duran, M.; Aday, M.S.; Zorba, N.N.D.; Temizkan, R.; Büyükcan, M.B.; Caner, C. Potential of antimicrobial active packaging 'containing natamycin, nisin, pomegranate and grape seed extract in chitosan coating' to extend shelf life of fresh strawberry. Food Bioprod. Process. 2016, 98, 354-363. [CrossRef]

21. Leal, C.; Gouvinhas, I.; Santos, R.A.; Rosa, E.; Silva, A.M.; Saavedra, M.J.; Barros, A. Potential application of grape (Vitis vinifera L.) stem extracts in the cosmetic and pharmaceutical industries: Valorization of a by-product. Ind. Crops Prod. 2020, 154, 112675. [CrossRef]

22. La Paz, S.M.-D.; Fernández-Arche, M.; Bermúdez, B.; Garcia-Gimenez, M.D. The sterols isolated from evening primrose oil inhibit human colon adenocarcinoma cell proliferation and induce cell cycle arrest through upregulation of LXR. J. Funct. Foods 2015, 12, 64-69. [CrossRef] 
23. Martins, N.; Barros, L.; Ferreira, I.C. In vivo antioxidant activity of phenolic compounds: Facts and gaps. Trends Food Sci. Technol. 2016, 48, 1-12. [CrossRef]

24. Atolani, O.; Adamu, N.; Oguntoye, O.; Zubair, M.; Fabiyi, O.; Oyegoke, R.; Adeyemi, O.; Areh, E.; Tarigha, D.; Kambizi, L.; et al. Chemical characterization, antioxidant, cytotoxicity, Anti-Toxoplasma gondii and antimicrobial potentials of the Citrus sinensis seed oil for sustainable cosmeceutical production. Heliyon 2020, 6, e03399. [CrossRef]

25. Kouka, P.; Chatzieffraimidi, G.-A.; Raftis, G.; Stagos, D.; Angelis, A.; Stathopoulos, P.; Xynos, N.; Skaltsounis, A.-L.; Tsatsakis, A.; Kouretas, D. Antioxidant effects of an olive oil total polyphenolic fraction from a Greek Olea europaea variety in different cell cultures. Phytomedicine 2018, 47, 135-142. [CrossRef]

26. De Santana, F.C.; Shinagawa, F.B.; Araujo, E.D.S.; Costa, A.M.; Mancini-Filho, J. Chemical Composition and Antioxidant Capacity of Brazilian Passiflora Seed Oils. J. Food Sci. 2015, 80, C2647-C2654. [CrossRef]

27. Margraf, T.; Karnopp, A.R.; Rosso, N.D.; Granato, D. Comparison between Folin-Ciocalteu and Prussian Blue Assays to Estimate The Total Phenolic Content of Juices and Teas Using 96-Well Microplates. J. Food Sci. 2015, 80, C2397-C2403. [CrossRef]

28. Santos, J.S.; Brizola, V.R.A.; Granato, D. High-throughput assay comparison and standardization for metal chelating capacity screening: A proposal and application. Food Chem. 2017, 214, 515-522. [CrossRef]

29. Berker, K.I.; Olgun, F.A.O.; Ozyurt, D.; Demirata, B.; Apak, R. Modified Folin-Ciocalteu Antioxidant Capacity Assay for Measuring Lipophilic Antioxidants. J. Agric. Food Chem. 2013, 61, 4783-4791. [CrossRef]

30. Carter, P. Spectrophotometric determination of serum iron at the submicrogram level with a new reagent (ferrozine). Anal. Biochem. 1971, 40, 450-458. [CrossRef]

31. Väisänen, T.; Kilpeläinen, P.; Kitunen, V.; Lappalainen, R.; Tomppo, L. Effect of steam treatment on the chemical composition of hemp (Cannabis sativa L.) and identification of the extracted carbohydrates and other compounds. Ind. Crops Prod. 2019, 131, 224-233. [CrossRef]

32. Gremski, L.A.; Coelho, A.L.K.; Santos, J.S.; Daguer, H.; Molognoni, L.; do Prado-Silva, L.; Sant'Ana, A.S.; Rocha da Silva, R.; da Silva, M.C.; Cruz, A.G.; et al. Antioxidants-rich ice cream containing herbal extracts and futooligossaccharides: Manufacture, functional and sensory properties. Food Chem. 2019, 298, 125098. [CrossRef] [PubMed]

33. Zhang, L.; Santos, J.S.; Cruz, T.M.; Marques, M.; Carmo, M.A.V.D.; Azevedo, L.; Wang, Y.; Granato, D. Multivariate effects of Chinese keemun black tea grades (Camellia sinensis var. sinensis) on the phenolic composition, antioxidant, antihemolytic and cytotoxic/cytoprotection activities. Food Res. Int. 2019, 125, 108516. [CrossRef] [PubMed]

34. Fidelis, M.; Santos, J.S.; Escher, G.B.; Carmo, M.V.D.; Azevedo, L.; da Silva, M.C.; Putnik, P.; Granato, D. In vitro antioxidant and antihypertensive compounds from camu-camu (Myrciaria dubia McVaugh, Myrtaceae) seed coat: A multivariate structure-activity study. Food Chem. Toxicol. 2018, 120, 479-490. [CrossRef] [PubMed] 